\title{
Professionalization, Local Military Context, and Reconstruction of the Army in Afghanistan
}

\author{
Cenker Korhan Demir \\ Gendarmerie and Coast Guard Academy
}

\begin{abstract}
Security sector reconstruction is a long-debated topic in the peacekeeping and state-building literature. The primary goal of any reconstruction program in conflict-ridden countries is to build up security institutions, which are prerequisites for sustainable development and democratization. This study aims to examine how security sector institutions, specifically the army, have been reconstructed by intervening actors in post-conflict countries like Afghanistan. It argues that army reconstruction programs that are developed without any elaboration of the peculiar conditions of the related post-conflict countries, are unlikely to be successful. As such, initiatives aimed at security sector reconstruction need to take account of the idiosyncratic characteristics of the conflict affected country and its institutions, and the program should be devised conforming to the casespecific circumstances. This research aims to identify reliable evidence to support this argument by analyzing data collected from both primary and secondary resources. It also aims to contribute methodologically by building upon the firsthand impressions of practitioners from various countries over their reconstruction activities.
\end{abstract}

Keywords: Afghanistan, reconstruction, security, army, professionalization

\section{Introduction}

The principal aim of security sector reform (SSR) is to establish security structures that will be efficient and effective in their use of resources, which are able to function under civilian control, and conspicuously, to provide security to the population. ${ }^{1}$ The broad approach to SSR makes it an essential component of state-building efforts, particularly in post-conflict environments. SSR and state-building agendas aim not only to reconstruct security institutions but also to reform social, political and economic structures as complementary parts of the overall program. ${ }^{2}$

The initiative of SSR has political (objective and subjective civilian control), social (provision of physical security for people), economic/development (minimal resource use),

Cenker Korhan Demir, Assoc.Prof.Dr., Gendarmerie and Coast Guard Academy, Ankara. Email: ckdemir@gmail.com. 0000-0001-8016-7123

${ }^{1}$ Heiner Hänggi, "Conceptualizing Security Sector Reform and Reconstruction," in Reform and Reconstruction of the Security Sector, ed. Alan Bryden and Heiner Hänggi (Geneva: Center for the Democratic Control of Armed Forces, 2004), 8; Michael Brzoska and Andreas Heinemann-Grüder, "Security Sector Reform and Post-Conflict Reconstruction under International Auspices," in Reform and Reconstruction of the Security Sector, ed. Alan Bryden and Heiner Hänggi (Geneva: Center for the Democratic Control of Armed Forces, 2004), 123.

2 Paul Jackson, "Security Sector Reform and State Building," Third World Quarterly 32, no. 10 (2011): 1812. 
and institutional (professionalization of armed forces, police and paramilitary) dimensions. ${ }^{3}$ By focusing on SSR's institutional aspects, this study examines how security sector institutions such as military forces have been reconstructed by intervening actors in postconflict environments. It seeks also to assess the strengths and flaws of the process. It is argued that army reconstruction initiatives that are devised by western countries without consideration of the idiosyncratic characteristics of respective countries and their armies, will not necessarily be successful in providing a resilient peaceful environment.

These efforts have received a surge of attention from practitioners and academicians in order to analyze the effectiveness of the process and utilize the improved program of reconstruction elsewhere. Although there are research studies based on the views and experiences of practitioners in the field over the professionalization of armies in accordance with reconstruction programs, the article strives to contribute to that knowledge by interviewing practitioners from different nations, all of whom have served in Afghanistan.

The following section, aiming to harmonize the studies about military and peace studies, begins with the reconstruction of militaries. The professionalization of armies and understanding of local military context have been brought into the study to reveal a distinctive approach to security sector reconstruction. After methodological discussions, the article delves into the specific security sector reconstruction programs in Afghanistan, as it has been suffering from protracted wide-range disturbances and political turmoil for many decades. For this very reason, Afghanistan has also been the subject of reconstruction programs developed by multinational actors.

\section{Security Sector Reform in Post-Conflict Countries}

Security Sector Reform as a concept coined by the UK Secretary of State in 1999, has come up against the "train and equip security assistance" model of the Cold War, to draw attention to a people-centered approach over security, and imply the nexus between security and development. ${ }^{4}$ There are three models in SSR referred to as "monopoly", "good enough" and "hybrid." The first two share the characteristic of being state-centric, while the last considers the role of non-state authorities in providing security. Liberal notions like participation, ownership, and political empowerment are the building blocks of the "hybrid school."5

SSR has four essential common preconditions for effective implementation, namely, a stable security environment, political consensus, a minimum level of human and institutional capacity, and durable resources, none of which can be easily found in conflict-affected countries. ${ }^{6}$ Recognizing security as a precursor of long-term peace, the provision of safety, security and justice has been accepted as the ostensible aim of any SSR process in these countries. ${ }^{7}$ SSR might also ensure favorable conditions to build or reform other governmental institutions of conflict-ridden states, since it has been mostly treated as a tool of state-building programs.

The circumstances of post-conflict countries, however, are laden with a number of specific challenges such as politicization, ethnicization, corruption of the security services, excessive

\footnotetext{
3 Michael Brzoska, "Introduction: Criteria for Evaluating Post-Conflict Reconstruction and Security Sector Reform in Peace Support Operations," International Peacekeeping 13, no. 1 (2006): 3.

4 Mark Sedra, Security Sector Reform in Conflict-Affected Countries: The Evolution of a Model (London: Routledge, 2017$), 56$.

Sedra, Security Sector Reform, 286-92.

6 Sedra, Security Sector Reform, 167.

Nadine Ansorg and Eleanor Gordon, "Co-operation, Contestation and Complexity in Post-Conflict Security Sector Reform," Journal of Intervention and Statebuilding 13, no. 1 (2019): 3
} 
military spending, lack of professionalism, poor oversight, and inefficient allocation of resources. ${ }^{8}$ The execution of SSR in such environments is thus dubbed as "security sector reconstruction". ${ }^{9}$ Although both settings are similar, security sector reconstruction activities are seen as being able to be performed under severe armed conflict, and they particularly deal with the legacy of past conflict while developing governmental institutions in post-conflict states lest any further conflict emerges in the future. ${ }^{10}$

Security sector reconstruction reflects the model of the "monopoly school" of SSR, which prioritizes institutionalization and the notion of the Weberian state that keeps power hegemony on its own. ${ }^{11}$ Therefore, the creation of military and police forces is acknowledged as the first endeavor to begin any state building program. ${ }^{12}$ Once having achieved a minimum security environment, according to this approach, the remaining parts of the program can progress efficiently and harmoniously. ${ }^{13}$

The SSR model relies on the presumption that a powerful state is the best means of delivering security and stability. Nevertheless, it is a demanding and multifaceted problem since the state structures in post-intervention countries have often collapsed, and nonstatutory security institutions challenge the existence of new security organizations. This situation inevitably entails a multinational presence, particularly in the initial phase of postconflict settings. Yet, an enduring security environment cannot be successfully developed solely through the activities of international actors. Their presence needs the consent and support of local actors in order to build up reliable security and governance institutions. Externally sponsored SSR needs to be compatible with particular historical-cultural features of the country rather than being based solely on the experiences of the donors. ${ }^{14}$ In order to address critiques of the monopoly school about unawareness of local norms, security sector reconstruction should devise comprehensive planning that considers local demands and synchronized implementation of activities by international and domestic actors. ${ }^{15}$

\section{The Reconstruction of Military Institutions}

One essential part of security sector reconstruction is to rebuild or to reform and train security institutions and support them by means of material, economic, and human resources. ${ }^{16}$ This point could be achieved by professionalizing the security structure to perform its duties well under civilian supervision.

It is contended that security sectors incorporate both statutory (e.g. armed forces, border guards, intelligence services, gendarmerie, penal institutions, and police) and non-statutory (e.g. guerrilla groups, militias, and private military and security companies) security institutions. ${ }^{17}$ Alternatively, what the OECD calls a "security system" includes four main components: core security actors (armed forces, police, gendarmeries, paramilitary forces,

8 Brzoska, "Introduction," 1.

9 Hänggi, "Conceptualizing," 1.

10 Hänggi, "Conceptualizing," 14.

11 Sedra, Security Sector Reform, 288.

12 Francis Fukuyama, "Building Democracy after Conflict: Stateness First," Journal of Democracy 16, no. 1 (2005): 87.

13 Sedra, Security Sector Reform, 288.

14 Jackson, "Security Sector Reform," 1813.

15 Hänggi, "Conceptualizing," 8.

16 Albrecht Schnabel and Hans Georg Ehrhart, "Post-conflict Societies and the Military: Challenges and Problems of Security Sector Reform," in Security Sector Reform and Post Conflict Peacebuilding, ed. Albrecht Schnabel and Hans Georg Ehrhart (Tokyo: United Nations University Press, 2005), 2; Brzoska and Heinemann-Grüder, "Security Sector Reform," 123; Hänggi, "Conceptualizing," 8.

17 Sedra, Security Sector Reform, 59. 
presidential guards, intelligence and security services, coast guards, border guards, customs authorities, reserve or local security units); management and oversight bodies; maintenance of justice and the rule of law; and non-statutory security forces (liberation armies, guerrilla armies, private security companies, political party militias). ${ }^{18}$

The military plays a central role compared to other security structures by defending the state and nation against external adversaries and internal insurgency. ${ }^{19}$ Arguably, it is one of the most essential security institutions in a post-conflict peacebuilding environment, ${ }^{20}$ and the "professionalism of militaries" is argued to be a key norm of security sector governance. ${ }^{21}$ The reform in the military can also positively influence other sectors such as police and intelligence. ${ }^{22}$ Even though all sectors in a security reform program are dependent on each other, the reconstruction of military institutions has been elaborated for the purposes of this study.

\subsection{Professionalization of armies}

The professionalization of militaries is a widely discussed issue particularly by students and scholars of civil-military relations, though there is hardly any agreement on the common characteristics of military professionalism. One seminal piece argues that it comprises "corporateness", "expertness", and "responsibility",23 another contends that professionalism consists of "expertise", "group identity", "education/training", "ethics/loyalty", and "selfadministration". ${ }^{24}$ It has also been contended that "military professionalization" encompasses the introduction of modern military equipment and technology into the armed forces, the upgrading of training facilities and procedures, making recruitment and promotions less arbitrary, and developing professional cadres of specialist officers and military experts at various levels and branches of the armed forces. ${ }^{25}$

The military, as a profession, differs from others in many aspects since its client is the nation. Each military force has peculiar attributes emanating from their own geography, culture, threat perceptions, and history. In this regard, there are two main trends in armed forces: "institutional" and "occupational." These are not intended as a clear-cut separation, rather a spectrum along which the military forces are expected to have some features of both at some level. ${ }^{26}$

Institutional military forces are characterized by mostly normative values and norms. The expected behavior of soldiers in this understanding is to value and prioritize concepts like "duty", "honor", and "country". Soldiers generally enjoy high esteem from the larger society and are compensated by noncash benefits. ${ }^{27}$ It is argued that institutionalized security organizations are rule-governed, predictable, and have a distinctive organizational culture 22.

18 The OECD DAC Handbook on Security System Reform: Supporting Security and Justice (Paris: OECD Publishing, 2007),

The OECD DAC Handbook on Security System Reform, 124.

Schnabel and Ehrhart, "Post-conflict Societies," 2-6.

Brzoska, "Introduction," 2.

22 The OECD DAC Handbook on Security System Reform, 124.

3 Samuel Huntington, The Soldier and the State: The Theory and Politics of Civil-Military Relations (Cambridge: Harvard University Press, 1957), 11-8.

${ }^{24}$ Morris Janowitz, The Professional Soldier: A Social and Political Portrait (New York: Free Press, 1971), 6.

${ }_{25}$ Mehran Kamrava, "Military Professionalization and Civil Military Relations in the Middle East," Political Science Quarterly 115, no. 1 (2000): 69-70.

26 Charles C. Moskos, "Institutional/Occupational Trends in Armed Forces: An Update," Armed Forces and Society 12, no. 3 (1986): 377-82.

27 Moskos, "Institutional/Occupational Trends," 377-82. 
and character. They tend not to be corrupt or abusive of power, rather, adhering to the rule of law. ${ }^{28}$

On the other hand, the occupational approach to military forces mainly stems from the supply and demand relationships of the marketplace. This model suggests a priority of selfinterest rather than the demands and culture of the employing organization. The soldiers of occupational military forces give importance to material benefits such as salary and bonuses rather than moral values. ${ }^{29}$

Having been at the opposite side of the institutionalism spectrum, "patrimonial security organizations" are ruled by cronyism and nepotism, with essential qualities like discipline and promotion in the army being maintained through the exploitation of primordial cleavage or personal relations. Individuals who are part of this type of organization are also against political reforms that might threaten their current organizational exploitation, and they fear the loss of their own personal status. ${ }^{30}$ Restructuring a military force in relation to ethnic affiliation might create intra-corps jealousy, distorted chains of commands following an ethnic rather than the official order, fragile cohesion, and possibly disobedience. ${ }^{31}$ Patrimony leads to corruption and abuse of power, even as it endangers the integrity of the military, which is an essential feature of effective armies.

One could argue that the professionalization of armies has "tangible" and "intangible" aspects. The intangible ones, such as devotion to the nation, sense of duty, coherence and integrity among various levels of army, emanate from their own socio-cultural life and are vital institutional values to facilitate and reinforce through state-building processes in postconflict countries. Tangible aspects suggest the facilities, equipment, financial benefits, and written works like manuals and doctrines. Both of these aspects serve to understand the professionalization of armies in a complementary manner.

\subsection{Understanding the local military context}

SSR programs suffer mostly from lack of awareness about local socio-cultural values and historical narrative. Although the concept of SSR is well developed, there often appears a gap between policy and practice in the implementation phase of such programs, a phenomenon known as "conceptual-contextual divide". ${ }^{32}$ The context surrounding each institution comprises its own tradition, culture, history, as well as economic and political circumstances. Security sector reconstruction programs implemented in post-conflict countries are more prone to deteriorate without proper research on the particular characteristics of the reform context.

Although military organizations have some freedom to isolate their members from society and develop distinctive internal structures, they inevitably internalize and mirror some characteristics of the community at large. Particularly in a country where sectarian and regional divisions and corruption are widely seen, the military is also going to suffer from similar predicaments, and it's likely its members may attach to their local loyalties instead of rather than those to nation, state and its institutions.

Armies will be more affected by general norms and the social structure of the community

\footnotetext{
28 Eva Bellin, "The Robustness of Authoritarianism in the Middle East," Comparative Politics 36, no. 2 (2004): 145

29 Moskos, "Institutional/Occupational Trends," 377-82.

30 Bellin, "The Robustness of Authoritarianism," 145.

31 Florence Gaub, Rebuilding Armed Forces: Learning from Iraq and Lebanon (Carlisle: Strategic Studies Institute, 2011), 8.

32 Jane Chanaa, Security Sector Reform: Issues, Challenges and Prospects (New York: Oxford University Press, 2002), 61-2.
} 
as compared to the navy and air forces since both of the latter organizations rely mostly on specialized equipment and have fewer members than former. It is also argued that military organizations will be more likely to reflect the structures of the larger society if:

\footnotetext{
... the military is a mass, non-professional army with short terms of service, large relative to society; if it fights wars with high casualty rates that force the military rapidly to bring many new soldiers in as replacements, while limiting the amount of time recruits spend in military training that can socialize the recruits to new norms before they are sent into battle; and if goals other than military effectiveness are allowed to govern the norms and structures of the military. ${ }^{33}$
}

So, it is expected that unprofessional armies will bear the characteristics of their societies more than professional organizations. Unprofessional organizations will not likely be able to manage to develop their own tangible and intangible assets, and neither will be able to impose new formed identity/organizational culture on its members while responding to the challenges which threaten its very existence.

On the other hand, efforts to isolate the military from society by socializing its members with organizational training and culture might create an adverse effect in that it could alienate the military from society, particularly if members of the military are recruited from subgroups that are not acknowledged as representatives of the respected society. This might impair societal confidence in the military or its leaders, which can, in turn, weaken the military power of the state. ${ }^{34}$

Military professionalism entails and enhances expertise, responsibility, organizational culture and institutionalization of armies. Although the figures on modern equipment, technology, weapon systems, trained soldiers, profile of human resources (ethnic and sectarian composition) and promotion procedures are important to make first assessments on the reconstruction of armies, there are many other factors as well that are important in recognizing the whole picture. Because armies intrinsically contain various segments of a population, their professionalization is also affected by the society within. The culture, tradition and history of the armies and their reflection on the professionalization process could also have a plausible effect on the level of reconstruction effort success.

\section{Methodology}

Professionalism, awareness of the local military context, and the ultimate achievement of SSR programs are difficult to measure. Although some statistical measures such as quantitative measures on military education, number of soldiers and equipment, the cost of programs, figures about violence across the country, have been interpreted in this study, these are not sufficient instruments to make valid assessments. In order to keep in balance quantitative and qualitative measures, this study has also sought to explore implicit indicators, including public perceptions about security, public credibility of security sector institutions, corruption rates, tenure in military jobs, promotion procedures, and practitioners' comment on the effectiveness of the SSR program.

Therefore, the research seeks to investigate evidence collected through both primary and secondary sources, namely, the field experiences of security providers and reports over reconstruction process, to make valid program assessments. Interviews were carried out from

33 Stephen P. Rosen, "Military Effectiveness: Why Society Matters," International Security 19, no. 4 (1995): 29.

34 Rosen, "Military Effectiveness," 30. 
June 2014 - January 2015 and July 2017 - March 2018, and field observations as an advisor and staff officer during the time of the reconstruction of Afghanistan's military were made between June 2014 - January 2015. This study is limited in its being informed exclusively by the experiences of coalition personnel involved with security sector initiatives in Afghanistan.

Semi-structured interviews were conducted with advisors and staff officers who served in Afghanistan, to explore their field experiences in security sector reconstruction activities. A snowball sampling technique was used to contact participants as it was not possible to pre-identify the full profile and figures of people who were contributing to security sector reconstruction initiatives. ${ }^{35}$

Table 1- Interviewees by country of origin, role, served year and tour duration

\begin{tabular}{|c|c|c|c|c|}
\hline No. & Country of Origin & Served Year & Job/Role & Tour Duration \\
\hline 1 & Hungary & 2013 & Advisor & 6 months \\
\hline 2 & Italy & $2013-2014$ & Staff Officer & 10 months \\
\hline 3 & Italy & $2014-2015$ & Advisor & 7 months \\
\hline 4 & Netherland & 2012 & Advisor & 3 months \\
\hline 5 & Netherland & 2014 & Staff Officer & 6 months \\
\hline 6 & Romania & 2012 & $\begin{array}{c}\text { Advisor, } \\
\text { Staff Officer }\end{array}$ & 7 months \\
\hline 7 & The United Kingdom & $2014-2015$ & Advisor, & 13 months \\
\hline 8 & The United Kingdom & $2008-2009$ & Staff Officer & 1 year \\
\hline 9 & The United Kingdom & 2014 & Advisor & 7 months \\
\hline 10 & The United States & $2014-2015$ & Civilian Advisor & 13 months \\
\hline 11 & The United States & $2009-2010$ & Advisor, & 1 year \\
\hline 12 & The United States & $2014-2015$ & Staff Officer & 7 months \\
\hline 13 & The United States & $2009-2010$ & Staff Officer & 7 months \\
\hline 14 & Turkey & 2014 & Civilian Advisor & 6 months \\
\hline 15 & Turkey & Staff Officer & 6 months \\
\hline 16 & Turkey & Staff Officer & 6 months \\
\hline 17 & Turkey & $2008-2009$ & Advisor & 6 months \\
\hline 18 & Turkey & 2013 & Advisor & 6 months \\
\hline 19 & Turkey & 2015 & Ataff Officer & 6 months \\
\hline 20 & Turkey & 2004 & & \\
\hline
\end{tabular}

Interviews were conducted voluntarily with participants from Hungary (1), Italy (2), Netherland (2), Romania (1), the United Kingdom (3), the United States (4), and Turkey (7) as shown in Table-1. The served years of interviewees in Afghanistan ranged between 2004 and 2016, and length of tours varied from 3 to 13 months. All participants were male, and consisted of two civilians and 18 officers.

Most of the interviews were carried out face-to-face, though some were conducted online or by telephone, and the questionnaires were exchanged via e-mail. The interview process was considered to be complete after reaching the saturation point. Some of the questions asked to participants for the purposes of the study were as follows:

- Which role have/had you undertaken in your duty/duties? (advisor, staff, field, other)

- What have been the most important problems and achievements related to the engagement of the international community in the SSR process? (Please rank them according to their significance.)

\footnotetext{
35 Ranjit Kumar, Research Methodology (London: Sage Publications, 1999), 162.
} 
- What have been the most important problems and achievements related to host country's security apparatuses and governance in the SSR process? (Please rank them according to their significance.)

- What should have been done differently in this particular SSR process to make it more successful?

- In your opinion, what are the vital issues to undertake in an SSR process in post-conflict settings?

In order to scrutinize the research questions in a complementary manner, along with content analysis on interview texts, several reports were also examined as secondary sources for information. The Brookings Afghanistan Index, The Asia Foundation: A Survey of the Afghan People and Special Inspector General for Afghanistan Reconstruction (SIGAR) reports are among the examined documents examined for this study.

\section{Reconstruction of the Afghanistan National Army}

Afghanistan's SSR program was developed according to the Bonn Agreement of December 2001, which was a plan aimed at ensuring a sustainable peace in Afghanistan and agreed upon by local leaders and international donors. In April 2002, the Group of Eight (G8) nations met in Geneva, Switzerland, to map out divided responsibilities for the SSR in Afghanistan. The process was divided into five pillars, with each of them being allocated to a donor nation to oversee: military reform (U.S.); police reform (Germany); judicial reform (Italy); the disarmament, demobilization and reintegration of ex-combatants (Japan); and counter-narcotics (United Kingdom). The military reform process was designated as having two components: the creation of an Afghan National Army (ANA) and the reform of the Afghan Ministry of Defense. ${ }^{36}$

\subsection{The process of reconstruction of the Afghan National Army}

Although Afghanistan's SSR process was inaugurated officially in the spring of 2002, the reconstruction process of the ANA can be examined over four phases in which the first two cover the years 2001-2003 and 2004-2006 respectively. ${ }^{37}$ The $3^{\text {rd }}$ phase began as of 2007 and extended through 2014, which was the completion year of the International Security Assistance Force (ISAF). The $4^{\text {th }}$ phase of ANA reconstruction can be identified as the period beginning with Resolute Support (RS) in 2015 through 2017.

After the fall of the Taliban in 2001, there was no regular army in Afghanistan, but, rather, armed opposition groups. As a first attempt to provide immediate security, these groups were loosely gathered under the name of the Afghan Military/Militia Force (AMF), and they were financed by the U.S., completely autonomous from the Kabul government. ${ }^{38}$ During the $1^{\text {st }}$ phase, the SSR process was not able to progress effectively because of ongoing military operations by the U.S. forces. However, in May 2003, it was proclaimed that major combat operations had ended and "stabilization and reconstruction activities" were commencing. Accordingly, the ISAF mission, which was established in December 2001 and

${ }_{36}$ Mark Sedra, "Security Sector Reform in Afghanistan and Iraq: Exposing a Concept in Crisis," Journal of Peacebuilding \& Development 3, no. 2 (2007): 10.

37 Adam Grissom, "Shoulder-to-Shoulder Fighting Different Wars: NATO Advisors and Military Adaptation in the Afghan National Army 2001-2011," in Military Adaptation in Afghanistan, ed. Theo Farrell, Frans Osinga, and James A. Russell (California: Stanford University Press, 2013), 263.

38 Antonio Giustozzi, "Auxiliary Force or National Army? Afghanistan's 'ANA' and the Counter-Insurgency Effort 2002 2006," Small Wars and Insurgencies 18, no. 1 (2007): 47. 
was concentrated in Kabul and its surrounding area, assumed control of the force in August 2003 and reached nationwide coverage in October $2006 .{ }^{39}$ The $2^{\text {nd }}$ phase not only confirmed NATO's control across the country but also indicated the beginning of the SSR program. The AMF, sometimes called a transitional army, was demobilized and the reconstruction of the ANA began.

In the third phase, the ANA infrastructure was developed through the restructuring of operational units and the opening of national and multinational training centers and specialist schools across the country. The structure of kandak (a unit equal to a battalion) was improved by including new units such as weapons, medical, signal, maintenance and support. Special units such as commandos, special forces, counternarcotics, highway security, support and logistics, quick reaction forces, and Afghan Air Forces were also founded. ${ }^{40}$

After transitioning from ISAF to RS in 2015, the U.S. and NATO forces began to provide training, advisory support, and assistance to the Afghan National Defense and Security Forces (ANDSF) through four regional (North, East, South, West), one capital (Kabul) and one functional (air capabilities) "Train, Advise, and Assist Commands" (TAACs). The objective of the RS mission was stated as being to "develop Afghan leadership, advice on Afghan reforms for fighting corruption, and most importantly, optimize ANDSF capabilities and resources to defend and protect Afghanistan from its enemies." RS thus developed eight Essential Functions that provided the framework and guidelines for fulfilling its tasks. ${ }^{41}$

The size of the Afghan military was increased to higher levels than were foreseen at the beginning. During the $1^{\text {st }}$ phase, the AMF was kept at symbolic numbers and organizational structure due to optimistic expectations about the security environment. The feeling was that security beyond the borders would be carried out by coalition forces while internal security would be provided by local forces. Accordingly, the US advocated the creation of a force no larger than 50,000. The initial US plan was to develop an army corps to deal with internal problems, and then withdraw from Afghanistan by the end of $2004 .{ }^{42}$

However, by 2004, the Taliban had reinvigorated itself and boosted its attacks particularly in the east and southeast of Afghanistan. The worsening security situation in Afghanistan was described as "volatile, having seriously deteriorated in certain parts of the country" by the UN. There were at least three essential causes of an upsurge of insecurity at that time, namely, anti-government spoiler groups, warlordism, and narcotics trade - alias a "shadow economy." ${ }^{\prime 3}$ Thus, the idea of having respectively small numbers of soldiers in organizations such as the Afghan National Guard and AMF was swiftly replaced by the ANA, since the security threat originating mainly from the Taliban had been continuing and the military capability of the AMF was hardly adequate as a coherent force to counter it. With the deteriorating security situation, the strength of the ANA reached 181,439, including civil

39 Sedra, Security Sector Reform, 168

40 Grissom, "Shoulder-to-Shoulder Fighting," 268-71.

41 Essential Functions (EF): EF-1: plan, program, budget, and execute; EF-2: transparency, accountability, and oversight; EF-3: civilian governance of the Afghan security institutions and adherence to rule of law; EF-4: force generation; EF-5: sustain the force; EF-6: plan, resource, and execute effective security campaigns; EF-7: develop sufficient intelligence capabilities and processes; EF-8: maintain internal and external strategic communications capability. See for detailed information, Resolute Support (RS) Afghanistan, Mission, accessed July 27, 2018, https://rs.nato.int/about-us/mission.aspx.

42 Special Inspector General for Afghanistan Reconstruction (SIGAR) Reconstructing the Afghan National Defense and Security Forces: Lessons from the US Experience in Afghanistan, September 23, 2017, accessed July 17, 2019, https://www.sigar. mil/AllReports/, 16.

43 Mark Sedra, "Consolidating an Elusive Peace: Security Sector Reform in Afghanistan," in Reform and Reconstruction of the Security Sector, ed. Alan Bryden and Heiner Hänggi (Geneva: Center for the Democratic Control of Armed Forces, 2004$), 210-11$. 
personnel, as of May 2014. ${ }^{44}$

There were training efforts from the very beginning of the reconstruction process. First, battalions trained by Britain, and soon after followed by the U.S., created the units of the Afghan National Guard. The process, however, lasted only ten weeks and was comprised of just primary soldiering and basic small unit tactics. ${ }^{45}$ It was impossible for these efforts involved in the training of small army units by Special Forces along with regular units to be successful in such a short time.

Beginning by early 2003, the U.S. Army conventional forces had taken over training responsibility, ${ }^{46}$ under the supervision of Task Force Phoenix. Task Force Phoenix was itself subordinate to the US Office of Military Cooperation-Afghanistan (OMC-A), which was overseeing overall development of the ANA. The name of this body would change to the Office of Security Cooperation-Afghanistan (OSC-A) in 2005, and to the Combined Security Transition Command-Afghanistan (CSTC-A) in 2006. Subsequently, as a multinational endeavor to develop unity of effort, NATO Training Mission-Afghanistan (NTM-A), the partner organization of CSTC-A, was established in 2009, with the main mission of overseeing NATO training delivered to the ANDSF. Later, with the ending of the ISAF operation, the functions of the NTM-A were integrated into the RS mission. ${ }^{47}$

The training of Afghan Armed Forces was carried out by three national academic institutions along with local training centers. The oldest local training institution in the country, the Kabul Military Training Centre (KMTS), began its activities on 14 May 2002, with the goal of offering 16-week basic infantry training. The National Military Academy of Afghanistan (NMAA), the Afghan National Army Officer Academy (ANAOA), and the Non-Commissioned Officer (NCO) Academy (NCOA) all operated under the umbrella of the Marshal Fahim National Defense University (aka. Afghan National Defense University) which was established in 2013. The NMAA, founded in 2012, delivers a four-year college level bachelor's degree to the officer candidates of the ANA and Afghan Air Force (AAF). Serving as a Junior Officer Academy, the ANAOA accepted its first candidates in 2013 and follows a 42-week education schedule. The trainees of education in the NCOA are sergeant candidates. $^{48}$

\subsection{Strengths and weaknesses of the program}

Although the reconstruction programs in Afghanistan have been progressing for approximately 18 years, there seems to be little or no definitive progress in the security situation across the country. It is reported that the conflict has reached a stalemate that appears to be recognized by all sides.$^{49}$ According to some public research, around $60 \%$ of the Afghan people believe that the country is headed in the wrong direction, and that the main reason for this is security

44 Special Inspector General for Afghanistan Reconstruction (SIGAR), Quarterly Report to the United States Congress, July 30, 2014, accessed July 31, 2019, https://www.sigar.mil/pdf/quarterlyreports/2014-07-30qr.pdf. The figures on ANA strength have been classified since 2015 .

45 Grissom, "Shoulder-to-Shoulder Fighting," 265.

46 Special Inspector General for Afghanistan Reconstruction (SIGAR) Reconstructing the Afghan National Defense and Security Forces: Lessons from the US Experience in Afghanistan, September 23, 2017, accessed July 17, 2019, https://www.sigar. mil/AllReports/, 19.

47 Sedra, Security Sector Reform, 172-73.

48 Author's observation.

49 The Asia Foundation, A Survey of the Afghan People: Afghanistan in 2018, accessed September 11, 2019. https:// asiafoundation.org/wp-content/uploads/2018/12/2018_Afghan-Survey_fullReport-12.4.18.pdf, 43. 
issues. ${ }^{50}$ Nearly $70 \%$ of Afghan people fear for their own safety. ${ }^{51}$ There is, indeed, some evidence for this perception of insecurity. According to the Uppsala Conflict Data Program, violence over the last decade has been rising in Afghanistan (Figure-1). ${ }^{52}$ In fact, the number of conflict-related deaths after 2014 has surpassed previous records.

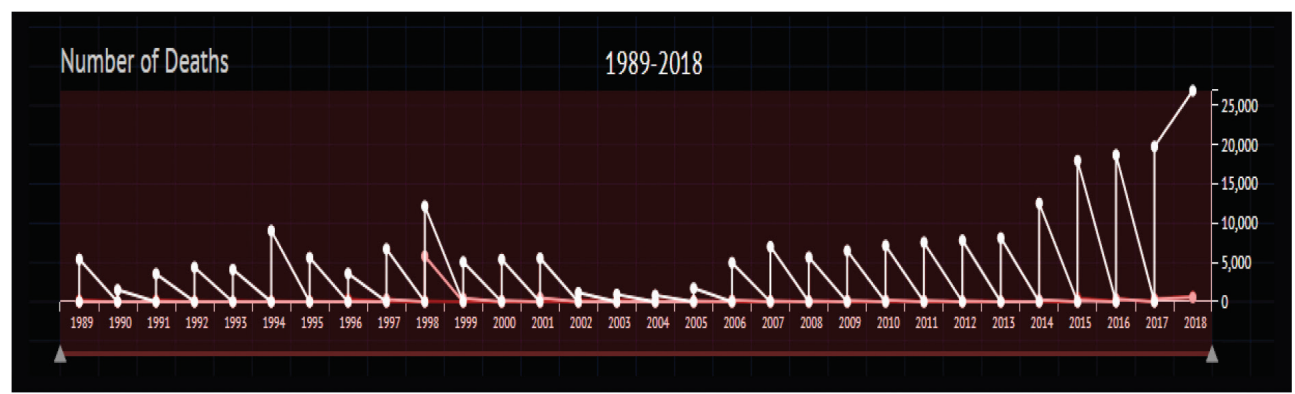

Figure 1: Number of Conflict-Related Deaths in Afghanistan

The data on security have raised questions over the effectiveness of the reconstruction process of the ANA. With this in mind, this study conducted interviews with practitioners, collecting information that was then grouped thematically concerning the flaws and strengths of the various reconstruction initiatives. According to the views of the interviewed participants, there have been achievements with respect to five aspects through the reconstruction process, as seen in Figure-2. The decreasing level of violence, particularly in some parts of country, immediately after the initial intervention, is the first success of operation. Financial support to reconstruct the governmental institutions and military in particular follow close behind.

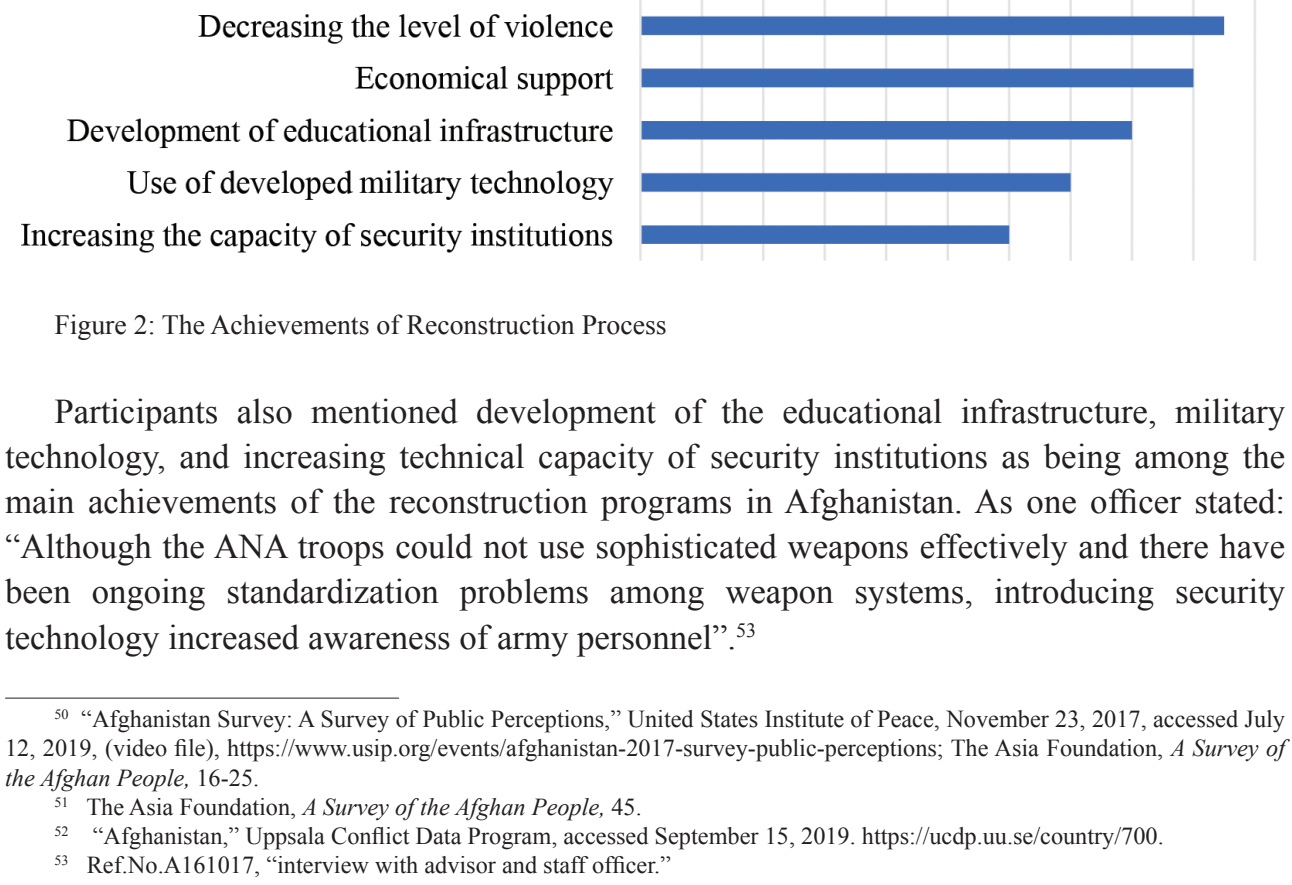


However, the programs have also faced clear problems, as seen in Figure-3. The most important issues raised by the participants are the ongoing insecurity between the warring factions, and corruption among local incumbents. Although the level of violence did decrease immediately after the operation, a fact pointed out as an accomplishment of the coalition forces, the lessening of security problems was not able to maintained over time.

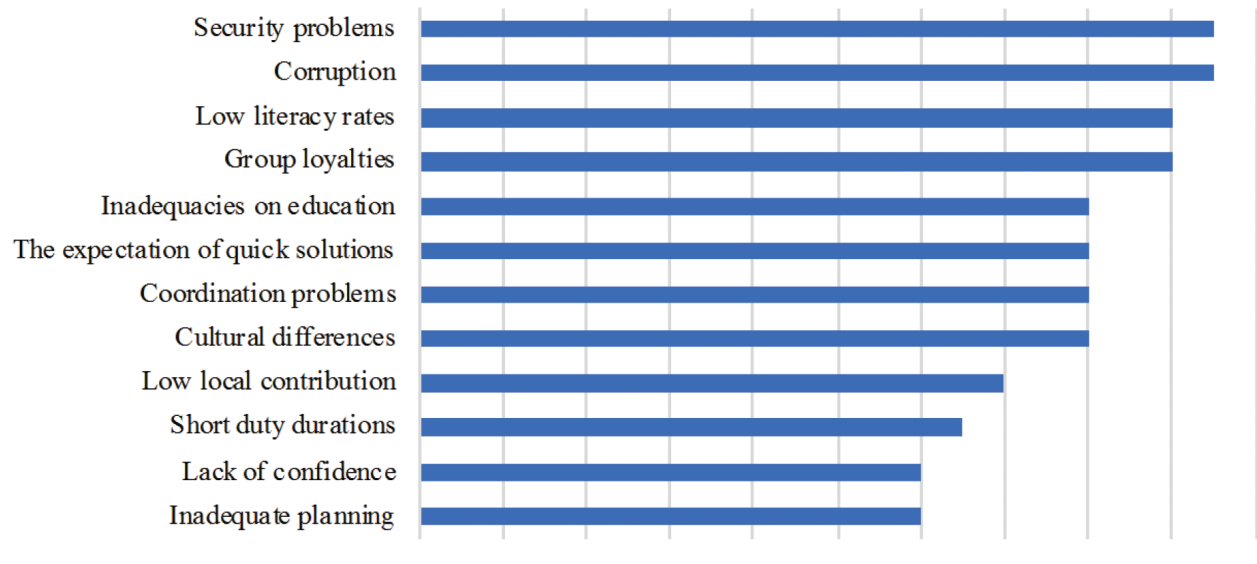

Figure 3: Problems Faced Throughout the Reconstruction Process

The ANA was torn between two opposite conceptualizations of its role, namely, acting as the auxiliary indigenous force of an occupying power, and becoming a "national army" able to secure the monopoly of force for the Afghan government and to serve its internal and foreign policy aims. ${ }^{54}$ Early U.S. plans were focused substantially on U.S. military operations and the mitigation of violence with the end purpose of withdrawing American troops out of Afghanistan as quickly as possible. As security began to deteriorate, goals for the reconstruction of the army in Afghanistan were altered dramatically to the purpose of quickly increasing the number of trained militias and soldiers to be ready for combat needs, even if they were not satisfactory in combat proficiency. For example, the first commando battalion, which is generally tasked with counterterrorism operations, was not fully trained by $2007 .{ }^{55}$ According to NATO assessments in 2011, nearly two-thirds of the ANA was still unable to function without constant ISAF assistance, even though they were considered autonomous on subjective evaluations. ${ }^{56} \mathrm{~A}$ wide majority of the people in Afghanistan (85\%), according to a survey, also believe that the ANA needs foreign support to do its job properly. ${ }^{57}$

Given the lack of modern technical and operational knowledge and equipment amongst the AMF, the trainers necessarily had to introduce and teach about issues that were almost completely unfamiliar to the soldiers, particularly in the first phase of the reconstruction program. High illiteracy rates, a prevalent problem among the Afghan population, impeded the candidates'/students' understanding of the courses content. Beyond issues of low literacy, one of the most important impediments was that the groups under the umbrella of the AMF

\footnotetext{
${ }^{54}$ Giustozzi, "Auxiliary Force or National Army," 48.

55 SIGAR, Reconstructing the Afghan National Defense and Security Forces, 41.

56 Grissom, "Shoulder-to-Shoulder Fighting," 273.

57 The Asia Foundation, A Survey of the Afghan People, 57.
} 
continued to adhere to their own sectarian (ethnic/religious/family/tribe) group leaders. ${ }^{58}$ These parallel loyalties to warlords alongside the official commanders severely lessened the levels of discipline, institutional integrity, and solidarity. These issues were even further exacerbated by the lack of weaponry, technology, and the undeveloped cadre, all of which weakened military effectiveness.

The ethnic composition of the ANA has long been an issue for the reconstruction program and its success. From the outset, Tajiks were represented in the ANA disproportionately compared to their share in the general population. The coalition and Ministry of Defense implemented a quota system in 2003, which brought about improvement by $2010 .{ }^{59}$ According to the Brookings Afghanistan Index, as of March 2013, four main ethnic groups comprised $87 \%$ of overall ANA personnel structure, while two of them, Pashtuns (42.4\%) and Tajiks (39.1\%), held the upper hand in terms of officer status. ${ }^{60}$ It is important to note however, that ethnic, tribal and sectarian differences are still pointed out by most of the interviewees in this study as being an essential impediment to developing a professionalized and effective military force. ${ }^{61}$

One of the most important internal obstacles in the reconstruction programs has been the repudiation of the social and historical heritage of the army in Afghanistan. Although there were early efforts to (re)build the regular army in Afghanistan, the primacy of tribal and local loyalty impeded the process. The Afghan government traditionally relied on three military institutions: the regular army, tribal levies, and community militias. The capability of the regular forces in guerilla warfare was supplemented by the two other armed groups. Since it was always difficult to develop a feeling of nationality over tribal allegiance, these forces were employed in a complementary way. ${ }^{62}$ Tribalism and sectarianism remained at the core of personal identity while national consciousness and an overarching sense of loyalty to the state remained weak, particularly among rank and file soldiers. ${ }^{63}$

Nevertheless, the local leaders were employed as leverage for ending the conflict; and local armed groups had been revitalized at the expense of armies by occupying countries such as Britain, the USSR and the US. ${ }^{64}$ Local leaders, tribal elders and local shura remain still among the most trusted institutions in dispute resolution. ${ }^{65}$ So, while the militias have been winning against their enemies and earning respect from the community, being an Afghan soldier does not command much respect among the population. Furthermore, low literacy rates among the society and a rudimentary education system have also aggravated the shrinkage of the recruitment pool and inhibited the recruitment and education of capable and professionalized military officers. Therefore, it has always been difficult to attract young men with sufficient education for training as army officers. ${ }^{66}$

Moreover, attrition is still very common among the ANA troops. The ANA loses almost one-third of its members every year. For example, in 2016, a report found that the rates of

58 SIGAR, Reconstructing the Afghan National Defense and Security Forces, 16.

59 Sedra, Security Sector Reform, 176.

60. Ian S. Livingston and Michael O'Hanlon, Brookings Institution Afghanistan Index, September 29, 2017, accessed September 19, 2019. https://www.brookings.edu/wp-content/uploads/2016/07/21csi_20171002_afghanistan_index.pdf.

61 It is also observed by the author.

62 Ali A. Jalali, "Rebuilding Afghanistan's National Army," Parameters 32, no. 3 (2002): 75.

63 Stephanie Cronin, Armies and State-building in the Modern Middle East: Politics, Nationalism and Military Reform (London: B. Tauris, 2014), 110.

${ }^{64}$ Cronin, Armies and State-building, 84

65 "Afghanistan Survey".

66 Cronin, Armies and State-building, 100. 
attrition were $2.9 \%$ in August, $2.3 \%$ in September, and 3.1\% in October. ${ }^{67}$ Poor unit leadership, insufficient vetting of recruits, lack of equipment and support, substandard literacy rates, poor quality of life, and corruption could be stated as some of the reasons. ${ }^{68}$ Low salaries, being away from their families over a long time, and war fatigue have also contributed to the mounting attrition.

It can be argued that one other drawback to the reconstruction program arises from the beginning of RS mission, at which time TAACs came to employ routine support to ANDSF units in close proximity and to more remote locations when needed. However, this new job description kept coalition forces out of daily activities and, it is claimed, this posture significantly decreased the "touch-points" of the U.S. on ANDSF units, causing the United States to rely on ANDSF information to understand the forces' needs and struggles. ${ }^{69}$

In addition to local problems, one of the most important hindrances over restructuring the national army in Afghanistan emanated from the approach of the western forces themselves. Not only were the problems and development needs being identified by these foreign forces, but also the possible solutions were also being proposed and put into effect by them. As pointed out by one interviewee: ${ }^{70}$

\footnotetext{
Many advisors try to mimic their country modus operandi and doctrine in Afghanistan. The country is very much underdeveloped with tribal culture and in the middle of a brutal, savage civil war. It cannot work. Most of the Afghan Generals want little new doctrine or administrative modern guidance...
}

In a country where normative aspects of life are appreciated, western approaches to rebuild the military by emphasizing material features could not corroborate this initiative well. According to the comments of participants of this study, this approach created nothing more than a patron-client relationship and made Afghan authorities dependent on material prizes. As one interviewee argues: $:^{71}$

\footnotetext{
Because of international money pouring in, local reforms were mostly prize related. The bigger the prize, the more cooperation was on the table from local actors. This understanding allowed some of crucial points to be missed by local actors.
}

It is also pointed out that the U.S. was ill-prepared for the reconstruction process, and lacked proper doctrine, policies, and resources from the beginning of launching efforts for security sector assistance. ${ }^{72}$ There was a lack of a comprehensive plan before military intervention among the coalition governments as pointed out interviewees. One participant states: ${ }^{73}$

There has to be a clear, deliberate plan in place in order to establish a security institution; whether that's an Army or a Police Force. If there's no detailed plan, then all the money from other countries won't help, because it's going to the wrong places, or they are given equipment that they don't need, nor want... Plans need to focus on need, not wants.

67 SIGAR, Reconstructing the Afghan National Defense and Security Forces, 118.

68 SIGAR, Reconstructing the Afghan National Defense and Security Forces, 157.

69 SIGAR, Reconstructing the Afghan National Defense and Security Forces, xiii.

70 Ref.No. B41017, "interview with civilian advisor," October 2017.

71 Ref.No. A251117, "interview with staff officer," November 2017.

72 SIGAR, Reconstructing the Afghan National Defense and Security Forces, $\mathrm{x}$

73 Ref.No. B61117, "interview with advisor and staff officer," November 2017. 
The plans were to be based upon political considerations and objectives: "our political masters need to set clear military objectives for the SSR mission..."74 However, a reconstruction plan is not a definite endeavor but rather a living preparation, that needs to be assessed and refined through implementation.

Given the scarce economic development and ongoing security problems, the Afghan government has failed to disrupt the patron-client relationship. The SSR process, particularly the reconstruction of the army, has always been dependent on foreign intervention and international funds. As pointed out by most of the participants in this study, the process in Afghanistan was unsuccessful at gaining "buy-in" from the host country. Therefore, the dependency transformed the institutions to a "prize focused approach" at the expense of satisfying their own needs.

\section{Conclusion}

Security sector reconstruction is argued to be a complementary program of overall statebuilding initiatives, particularly in conflict-ridden countries. The complexity and high cost of such programs, alongside the scarcity of capabilities over essential services and infrastructures of local governments, require multinational initiatives. The prominent phase of any SSR process is to provide immediate security and reconstruction of local security institutions, armies in particular.

The reconstruction program of the Afghan army, as an example, has had some drawbacks. The participants of this study believe that multinational intervention suppressed the ongoing armed conflict swiftly and provided an acceptable level of security at the intervention period. However, problems emerged from the deficiencies in delivering a widespread safe and secure environment and sustainable peace across the country. The main reason for this failure has been ethnic and tribal differences among the Afghan population. The lack of awareness among the incumbents of the reconstruction processes related to the country's socio-cultural peculiarities and inefficiencies on planning over the initiatives after military intervention, have exacerbated the security condition as well.

There is a dearth of knowledge among the occupying powers about the intertwined role of the Afghan army and local armed groups in Afghanistan. The actors of security sector reconstruction in Afghanistan have largely tried to imitate their own perceptions of the military, which does not clearly fit the operation ground. Additionally, multinational actors taking part in the reconstruction programs engendered the fragmentation of the efforts, and decreased the effectiveness of the military.

As a result, the security sector reconstruction process of the army reflected the style of the western countries' own militaries. There is also convincing evidence derived from this study's interviews that reveal how western powers primarily valued the tangible aspects of professionalization. The investment in technological equipment and placing high importance on numbers of materiel or the quantity of personnel, could be considered as some examples.

The multinational actors have struggled to keep insecurity within the borders of Afghanistan in order to prevent devastating spill-over effects on the international security environment and threaten themselves in particular. It has been argued that the reconstruction agenda focused on creating a situation of "controlled insecurity". ${ }^{75}$ So, the underlying aim of

\footnotetext{
74 Ref.No. B71117, “interview with staff officer,” November 2017.

${ }^{75}$ Krastev, cited in Sedra, "Security Sector Reform in Afghanistan and Iraq," 21.
} 
the program was to reduce its possible contagion effect and swiftly withdraw its forces from the country.

Reconstruction of the security sector does not fit all situations, even if it is proven as an effective program in some other country. Planning endeavors should therefore acknowledge the history, socio-cultural life, and attitudes of the people and the institutions of respective countries, rather than having only technical knowledge about the reconstruction process. A nationally suitable model should be developed in accordance with this accumulated knowledge and public interests, since there are various approaches and perspectives on military-style. Hence, a comprehensive program over the reconstruction of armies in postconflict countries should be tailor-made.

\section{Bibliography}

Ansorg, Nadine, and Eleanor Gordon. "Co-operation, Contestation and Complexity in Post-Conflict Security Sector

Reform." Journal of Intervention and Statebuilding 13, no.1 (2019): 2-24.

Bellin, Eva. "The Robustness of Authoritarianism in the Middle East." Comparative Politics 36, no. 2 (2004): 139-57.

Bensahel, Nora. "Mission Not Accomplished: What Went Wrong with Iraqi Reconstruction." The Journal of Strategic Studies 29, no. 3 (2006): 453-73.

Brzoska, Michael. "Introduction: Criteria for Evaluating Post-Conflict Reconstruction and Security Sector Reform in Peace Support Operations.” International Peacekeeping 13, no. 1 (2006): 1-13.

Brzoska, Michael, and Andreas Heinemann-Grüder. "Security Sector Reform and Post-Conflict Reconstruction under International Auspices." In Reform and Reconstruction of the Security Sector, edited by Alan Bryden and Heiner Hänggi, 121-42. Geneva: Center for the Democratic Control of Armed Forces, 2004.

Chanaa, Jane. Security Sector Reform: Issues, Challenges and Prospects. New York: Oxford University Press, 2002.

Cronin, Stephanie. Armies and State-building in the Modern Middle East: Politics, Nationalism and Military Reform. London: I.B. Tauris, 2014.

Fukuyama, Francis. "Building Democracy After Conflict: Stateness First.” Journal of Democracy 16, no.1 (2005): 84-8.

Gaub, Florence. Rebuilding Armed Forces: Learning from Iraq and Lebanon. Carlisle: Strategic Studies Institute, 2011.

Giustozzi, Antonio. "Auxiliary Force or National Army? Afghanistan's 'ANA' and the Counter-Insurgency Effort, 2002-2006." Small Wars and Insurgencies 18, no. 1 (2007): 45-67.

Grissom, Adam. "Shoulder-to-Shoulder Fighting Different Wars: NATO Advisors and Military Adaptation in the Afghan National Army 2001-2011." In Military Adaptation in Afghanistan, edited by Theo Farrell, Frans Osinga, and James A. Russell, 263-87. California: Stanford University Press, 2013.

Hänggi, Heiner. "Conceptualizing Security Sector Reform and Reconstruction." In Reform and Reconstruction of the Security Sector, edited by Alan Bryden and Heiner Hänggi, 1-11. Geneva: Center for the Democratic Control of Armed Forces, 2004.

Hänggi, Heiner, and Vincenza Scherrer. "Towards an Integrated Security Sector Reform Approach in UN Peace Operations.” International Peacekeeping 15, no. 4 (2008): 486-500.

Huntington, Samuel. The Soldier and the State: The Theory and Politics of Civil-Military Relations. Cambridge: Harvard University Press, 1957.

Jackson, Paul. "Security Sector Reform and State Building." Third World Quarterly 32, no. 10 (2011): 1803-22.

Jalali, Ali A. "Rebuilding Afghanistan's National Army.” Parameters 32, no. 3 (2002): 72-86.

Janowitz, Morris. The Professional Soldier: A Social and Political Portrait. New York: Free Press, 1971.

Kamrava, Mehran. "Military Professionalization and Civil Military Relations in the Middle East." Political Science 
Quarterly 115, no. 1 (2000): 67-92.

Kumar, Ranjit. Research Methodology. London: Sage Publications, 1999.

Livingston, Ian S., and Michael O’Hanlon. Brookings Institution Afghanistan Index, September 29, 2017. Accessed 19 September, 2019. https://www.brookings.edu/wp-content/uploads/2016/07/21csi_20171002_afghanistan index.pdf.

Moskos, Charles C. "Institutional/Occupational Trends in Armed Forces: An Update." Armed Forces and Society 12, no. 3 (1986): 377-82.

Reference Number A161017, “interview with advisor and staff officer,” October 2017.

Reference Number A251117, “interview with staff officer,” November 2017.

Reference Number B41017, “interview with civilian advisor,” November 2017.

Reference Number B61117, "interview with advisor and staff officer," November 2017.

Reference Number B71117, “interview with staff officer,” November 2017.

Resolute Support (RS) Afghanistan. Mission. Accessed July 27, 2018. https://rs.nato.int/about-us/mission.aspx.

Rosen, Stephen P. “Military Effectiveness: Why Society Matters.” International Security 19, no. 4 (1995): 5-31.

Schnabel, Albrecht, and Hans Georg Ehrhart. "Post-conflict Societies and the Military: Challenges and Problems of Security Sector Reform." In Security Sector Reform and Post Conflict Peacebuilding, edited by Albrecht Schnabel and Hans Georg Ehrhart, 1-16. Tokyo: United Nations University Press, 2005.

Sedra, Mark. "Consolidating an Elusive Peace: Security Sector Reform in Afghanistan." In Reform and Reconstruction of the Security Sector, edited by Alan Bryden and Heiner Hänggi, 207-23. Geneva: Center for the Democratic Control of Armed Forces, 2004.

_. "Security Sector Reform in Afghanistan and Iraq: Exposing a Concept in Crisis." Journal of Peacebuilding \& Development 3, no. 2 (2007): 7-23.

Security Sector Reform in Conflict-Affected Countries: The Evolution of a Model. London: Routledge, 2017.

Special Inspector General for Afghanistan Reconstruction (SIGAR). Quarterly Report to the United States Congress. July 30, 2014. Accessed July 31, 2019. https://www.sigar.mil/pdf/quarterlyreports/2014-07-30qr.pdf.

Special Inspector General for Afghanistan Reconstruction (SIGAR). Reconstructing the Afghan National Defense and Security Forces: Lessons from the US Experience in Afghanistan. September 23, 2017. Accessed July 17, 2019. https://www.sigar.mil/AllReports/.

The Asia Foundation. A Survey of the Afghan People: Afghanistan in 2018. Accessed September 11, 2019. https:// asiafoundation.org/wp-content/uploads/2018/12/2018_Afghan-Survey_fullReport-12.4.18.pdf.

The OECD /DAC Handbook on Security System Reform: Supporting Security and Justice. Paris: OECD Publishing, 2007.

United States Institute of Peace. “Afghanistan 2017: A Survey of Public Perceptions November 23, 2017. Accessed July 12, 2019. Video, https://www.usip.org/events/afghanistan-2017-survey-public-perceptions.

Uppsala Conflict Data Program. “Afghanistan.” Accessed September 15, 2019. https://ucdp.uu.se/country/700. 